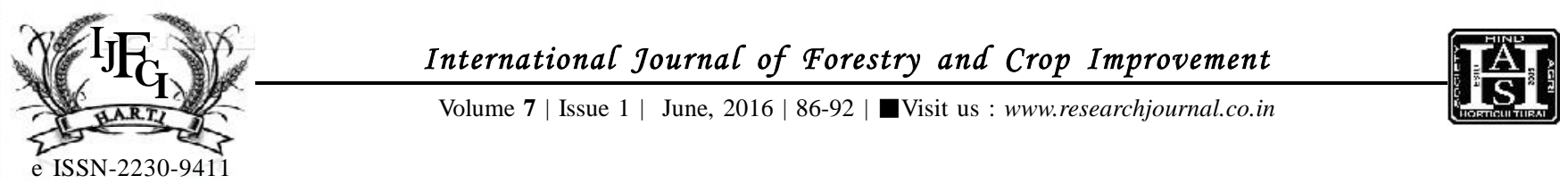

\title{
RAPD-PCR technique for molecular detection and diversity of Fusarium oxysporum f.sp. dianthi causing vascular wilt of carnation
}

\author{
PonNusAmy RAJeshKumar, PASUVARAJI AdHIPATHI and SEVUGAPERUMALNAKKEERAN
}

\begin{abstract}
Fusarium wilt disease is one of the major economic constraint which hampers carnation cut flower production. Thirteen isolates of Fusarium oxysporum f.sp. dianthi inciting vascular wilt of carnation were evaluated for their molecular characterization using random amplified polymorphic DNA (RAPD- PCR). The isolates were categorized based on the morphological characteristics, produced colonies with circular pattern growth. However, differences were obtained in colony colour, shape and size of conidia. The 5.8S-rDNA of ITS region was amplified the specific amplicon size of $398 \mathrm{bp}$ which confirmed the pathogen as Fusarium oxysporum. The molecular polymorphism among isolates were analysed by means of RAPD-PCR and the genetic coefficient matrix derived from the scores of RAPD profile showed that minimum and maximum per cent similarities and diversity among isolates were in the range of 70 to 96 per cent, respectively. The cluster analysis by un-weighted pair-group method with arithmetic average (UPGMA), separated the isolates into four clusters which confirming the genetic diversity among isolates.
\end{abstract}

KEY WORDS : Carnation, Fusarium oxysporum f.sp.dianthi, Molecular diversity, RAPD, Vascular wilt

How TO CITE THIS ARTICLE : Rajeshkumar, Ponnusamy, Adhipathi, Pasuvaraji and Nakkeeran, Sevugaperumal (2016). RAPD-PCR technique for molecular detection and diversity of Fusarium oxysporum f.sp. dianthi causing vascular wilt of carnation. Internat. J. Forestry \& Crop Improv., 7 (1) : 86-92, DOI: 10.15740/HAS/IJFCI/7.1/86-92.

Article Chronical : Received : 11.02.2016; Revised : 19.04.2016; Accepted : 21.05.2016 